\title{
Lehetséges összefüggés egy autizmusspektrum-zavarban érintett gyermek metilfenidát-kezelése és az azt követően kialakult gynaecomastia között
}

\author{
Kollárovics Nóra dr. ${ }^{1,2}$ - Nagy Péter dr. ${ }^{3}$ - Balázs Judit dr. ${ }^{4,5}$ \\ ${ }^{1}$ Semmelweis Egyetem, Mentális Egészségtudományok Doktori Iskola, \\ Pszichiátria Program, Gyermekpszichiátriai Kórképek Vizsgálata Munkacsoport, Budapest \\ ${ }^{2}$ Nemzetközi Cseperedő Alapítvány, Budapest \\ ${ }^{3}$ Bethesda Gyermekkórház, Figyelemhiányos Hiperaktivitás Zavar (ADHD) Ambulancia, Budapest \\ ${ }^{4}$ Eötvös Loránd Tudományegyetem, Pedagógiai és Pszichológiai Kar, Pszichológiai Intézet, \\ Fejlődés- és Klinikai Gyermekpszichológia Tanszék, Budapest \\ ${ }^{5}$ Bjørknes University College, Oslo, Norvégia
}

\begin{abstract}
Bár a figyelemhiányos hiperaktivitási zavar kezelése során alkalmazott metilfenidát-monoterápiával összefüggésben jelentkező gynaecomastiáról bizonyos nemkívánatos hatások adatbázisai beszámolnak, a szakirodalom áttekintése alapján ez idáig mindössze 5 esettanulmányt publikáltak a témában. Tanulmányunkban egy autizmusspektrum-zavarral és figyelemhiányos hiperaktivitási zavarral egyaránt diagnosztizált gyermek esetét mutatjuk be, akinél 6 hónapon át tartó, folyamatos metilfenidát-monoterápiájával összefüggésben kétoldali gynaecomastia kialakulását tapasztaltuk. A kezelés azonnali leállítása mellett 10 napos klomifénkezelés történt. A metilfenidát-terápia azonnali leállítását követően 14 nappal a gynaecomastia mindkét oldalon visszahúzódott. 3 hónapos, gyermekpszichiátriai szempontból gyógyszermentes időszakot követően a metilfenidát-terápia újraindítása történt, de 1 hónap elteltével a nem kívánt mellékhatás ismét jelentkezett. A metilfenidát-terápia és a gynaecomastia kialakulása közötti kapcsolat számos mechanizmussal kapcsolatban kérdéseket vet fel. Gyermekpszichiátriai szempontból érdekes kérdés, hogy releváns lehet-e a gyógyszeres terápia következményeként kialakuló nemkívánatos mellékhatás megjelenésében az autizmusspektrumzavar és a figyelemhiányos hiperaktivitási zavar komorbid fennállása. A jelenség hátterében felmerül továbbá a neuroendokrin-immunológiai rendszer szabályozásának esetleges megváltozása. Esettanulmányunk felhívja a gyakorló orvoskollégák figyelmét a metilfenidát-terápia alkalmazása mellett potenciálisan kialakuló gynaecomastia monitorozására.
\end{abstract}

Orv Hetil. 2021; 162(42): 1703-1708.

Kulcsszavak: figyelemhiányos hiperaktivitási zavar, autizmusspektrum-zavar, metilfenidát, gynaecomastia

\section{Possible association between methylphenidate treatment in a child with autism spectrum disorder and subsequent gynecomastia}

\begin{abstract}
Although gynecomastia associated with methylphenidate monotherapy in the treatment of attention deficit hyperactivity disorder has already been reported in some adverse event databases, based on a review of the literature it appears that only five case reports have been published. In our study, we present the case of a child diagnosed with both autism spectrum disorder and attention deficit/hyperactivity disorder, who developed bilateral gynecomastia in association with continuous methylphenidate monotherapy for 6 months. With immediate cessation of methylphenidate therapy, clomiphene treatment was given for 10 days. A total of 14 days after cessation of methylphenidate treatment gynecomastia receded on both sides. After a methylphenidate drug-free period of 3 months, methylphenidate therapy was restarted, but 1 month later the side effect reappeared. The relationship between methylphenidate and the development of gynecomastia raises questions about a number of mechanisms. From a child psychiatrist point of view, it is an interesting question whether the presence of comorbid autism spectrum disorder and attention deficit/
\end{abstract}


hyperactivity disorder may be relevant in the onset of adverse events by medication. The phenomenon may also be caused by altered regulation of the neuroendocrine-immune system. Our case report draws the attention of practicing physicians to monitoring of potential gynecomastia during methylphenidate therapy.

Keywords: attention deficit/hyperactivity disorder, autism spectrum disorder, methylphenidate, gynecomastia

Kollárovics N, Nagy P, Balázs J. [Possible association between methylphenidate treatment in a child with autism spectrum disorder and subsequent gynecomastia]. Orv Hetil. 2021; 162(42): 1703-1708.

(Beérkezett: 2021. február 1.; elfogadva: 2021. március 23.)

\begin{abstract}
Rövidítések
$\mathrm{ADHD}=($ attention deficit $/$ hyperactivity disorder $)$ figyelemhiányos hiperaktivitási zavar; ADHD-RS = (Attention Deficit $/$ Hyperactivity Disorder Rating Scale IV) Figyelemhiányos Hiperaktivitási Zavar Pontozóskála IV.; ASD = (autism spectrum disorder) autizmusspektrum-zavar; DHEA-S = dehidroepiandroszteron-szulfát; DSM-5 = (Diagnostic and statistical manual of mental disorders, 5 th edition) A mentális betegségek diagnosztikai és statisztikai kézikönyve, 5. kiadás; EMA = (European Medicines Agency) Európai Gyógyszerügynökség; FDA $=($ U.S. Food and Drug Administration) az Amerikai Egyesült Államok Élelmiszer-biztonsági és Gyógyszerészeti Hivatala; FSH = folliculusstimuláló hormon; $\mathrm{LH}=$ luteinizáló hormon; MINI-KID $=($ Mini International Neuropsychiatric Interview for Children) Gyermek Mini Nemzetközi Neuropszichiátriai Interjú; SDQ $=($ Strengths and Difficulties Questionnaire $)$ Képességek és Nehézségek Kérdőív
\end{abstract}

A figyelemhiányos hiperaktivitási zavar (attention deficit/hyperactivity disorder, ADHD) a leggyakrabban elóforduló idegrendszeri fejlődési zavarok egyike a gyermekpszichiátriában; a pszichés nehézségek miatti segítségkérés 30-50\%-a kifejezetten erre a problémára irányul $[1,2]$. Az ADHD krónikus állapot, mely folyamatos kezelést, ellenőrzést igényel [3]. A stimulánsok - például a metilfenidát - alkalmazása a leggyakoribb farmakológiai terápia az ADHD kezelésében [4]. Számos tanulmány támasztja alá a metilfenidát-terápia hatékonyságát az ADHD kezelésében [5], használata autizmusspektrum-zavar (autism spectrum disorder, ASD) fennállása esetén is javallott [6]. Szintén széleskörúen ismertek a metilfenidát leggyakoribb mellékhatásai, így az emelkedett pulzus és vérnyomás, az álmatlanság, a csökkent étvágy, a fogyás, a hasi fájdalom, a fejfájás, az ingerlékenység, a szorongás, a sírásra való hajlam, motoros tikek [7].

A gynaecomastia a mirigyszövet megnagyobbodása a férfiemlőben. A tünet megjelenése újszülöttkorban, pubertaskorban fiziológiás [8]. Praepubertaskorban a leggyakrabban idiopathiás, de patogén eredetú is lehet [9]. Ritkábban előfordul, hogy a patológiás emlőmegnagyobbodást bizonyos gyógyszerek (például a szív- és érrendszerre ható gyógyszerek, antibiotikumok, onkológiai készítmények vagy pszichoaktív szerek) alkalmazása vagy szerhasználat okozza. A pszichoaktív gyógyszerek közül idesorolhatók az amfetaminok, a diazepám, a metildopa, a fenitoin, a rezerpin, a triciklikus antidepreszszánsok, a haloperidol, valamint az atípusos antipszichotikumok $[9,10]$.

A metilfenidát-terápia és a gynaecomastia megjelenése közötti összefüggés tekintetében a szakirodalom áttekintése során elsősorban esettanulmányok voltak fellelhetők, összesen 5 publikációt találtunk. Emellett két összefoglaló tanulmányban szerepel specifikusan a metilfenidát a gynaecomastiával összefüggésben: ezek egyike általánosságban számol be a tünet kialakulásának lehetséges farmakológiai okairól, míg a másik posztmarketingadatok elemzésére fókuszál.

Bowman és mtsai [11] közleményében említésre kerül lehetséges ok-okozati összefüggés, az Amerikai Egyesült Államok Élelmiszer-biztonsági és Gyógyszerészeti Hivatalának (FDA) a „Nemkívánatos események jelentési rendszere" elnevezésû adatbázisában akkor fellelhető 8 regisztrált eset alapján. A munkacsoport elemzése alapján Maciejewski és mtsai [12] később ugyanezen adatbázis használata révén - amely ekkor már 35 regisztrált esetet tartalmazott a metilfenidát alkalmazása mellett kialakuló gynaecomastia tekintetében - az adatok feldolgozását követően ugyanakkor arra a következtetésre jutottak, hogy nincs szignifikáns összefüggés a metilfenidát-használat és a gynaecomastia kialakulása között.

Hoevenaren és mtsai [13] tanulmányukban egy 8 éves, ADHD-ban érintett fiú esetét mutatják be, akinél bizonytalan időtartamú metilfenidát- $(30 \mathrm{mg} / \mathrm{nap})$ és melatonin- ( $5 \mathrm{mg} / \mathrm{nap}$ ) kezelés mellett egyoldali gynaecomastia alakult ki. Endokrinológiai betegsége nem volt, ugyanakkor családi anamnézisében szerepelt praepubertalis kétoldalú gynaecomastia előfordulása. Mútéti kezelés történt; az esettanulmányban nincs információ további metilfenidát-alkalmazásról.

Ensat és mtsai [14] esettanulmányukban egy ADHDban érintett, praepubertaskorú kisfiú esetéról számolnak be, aki 4 éves korától fogva részesült metilfenidát-kezelésben $(10 \mathrm{mg} / \mathrm{nap})$, és akinél 6 éves korában alakult ki gynaecomastia. A gyermek 12 éves korában mastectomia vált szükségessé. Kiemelendő azonban, hogy a szerzők nem számolnak be esetleges társbetegség fennállásáról, továbbá a gyermek endokrinológiai statusáról, illetve a metilfenidát-terápia folytatásának részleteiről sem. 
Coskun és mtsai [15] egy 10 éves, ADHD-val és szociális szorongásos zavarral küzdő gyermek esetét publikálták, akinek kezelése során metilfenidát (18 mg/nap) és paroxetin $(10 \mathrm{mg} / \mathrm{nap})$ kombinált gyógyszeres terápiát alkalmaztak. A gyógyszeradagok beállítása során mindkét esetben dózisemelés történt, $54 \mathrm{mg} /$ nap dózisig a metilfenidát-, $20 \mathrm{mg} /$ nap dózisig a paroxetinterápia esetében. 6 hónappal az utolsó dózisemelést követően, illetve több mint 1,5 évvel a kombinált gyógyszeres kezelés megkezdése után kétoldali gynaecomastia volt azonosítható, amely „feltehetően több hónap alatt alakult ki” a szerzők beszámolója szerint. A tanulmány szerint valamennyi releváns endokrin paraméter a normáltartományon belül volt, a családi anamnézis negatív volt gynaecomastia és egyéb endokrinológiai betegségek tekintetében. A gyermek gyógyszeres terápiáját leállították, ám a tünet több mint fél éven át fennmaradt, az utolsó gyermekpszichiátriai megjelenés is ekkor volt.

Almis és mtsai [16] egy 9 éves, ADHD-ban érintett fiú esetét publikálták, akinél 23 napon át tartó metilfenidátterápiát $(18 \mathrm{mg} / \mathrm{nap})$ követően alakult ki gynaecomastia. Endokrin paraméterei a normáltartományon belül voltak, családi anamnézise negatív volt gynaecomastia és egyéb endokrinológiai betegségek vonatkozásában.

Karayagmurlu és mtsai [17] a közelmúltban publikálták esettanulmányukat egy 15 éves, ADHD-diagnózisú serdülő fiú kapcsán. A fiatalt több mint 2 évvel ezelőtt diagnosztizálták ADHD-val, akkor metilfenidát-terápia beállítása történt. Az elmúlt 2 évben a fiatal együttmúködése minimális volt, gyógyszerét nem szedte, gondozása nem valósult meg. Ismételt megjelenése és gondozásba vétele során metilfenidát-terápia ismételt beállítása történt $27 \mathrm{mg} / \mathrm{nap}$, majd 1 hónap elteltével $36 \mathrm{mg} / \mathrm{nap}$ dózisban. Következő kontrollja során - 1 hónap elteltével - emlőfeszülésről és emlőnövekedésről számolt be, amely pszichésen is megterhelő volt számára. Endokrinológiai vizsgálata során prolaktinszintje normálértéket mutatott, érzékenység vagy tejcsorgás sem volt észlelhető. Kétoldali gynaecomastia fennállása igazolódott. A metilfenidát-terápia azonnali elhagyását követően atomoxetinterápia indítása történt, melyet gyermekpszichiátriai állapotromlás miatt később riszperidonterápiával egészítettek ki. A fiatal gynaecomastiája visszahúzódott, kombinált atomoxetin-riszperidon terápia mellett gyermekpszichiátriai szempontból is kompenzálódott.

Jelen közleményünkben bemutatjuk egy ASD-ban és ADHD-ban egyaránt érintett gyermek esetét, akinél metilfenidát-monoterápiát követően tapasztaltuk gynaecomastia kialakulását.

\section{Esetbemutatás}

\section{Kórtörténet és diagnosztika}

A gyermekpszichiátriai gondozása kezdetén 10 éves kisfiú kivizsgálását a területi Pedagógiai Szakszolgálat kezdeményezte a Vadaskert Gyermekpszichiátriai Kórház és Szakambulancia (Budapest) intézményében figyelmi és tanulásbeli, valamint a társas kommunikáció és a társas beilleszkedés területein észlelt nehézségek miatt, amelyeket már bölcsődés- (2 éves) kora óta tapasztalt családja.

Prae-, peri- és postnatalis anamnézise negatív, fejlődéstörténetéből egyenetlen mozgás- és beszédfejlődés, sztereotip mozgások (lábujjhegyen járás, repkedés) emelendôk ki. Szomatikus és familiáris anamnézise negatív. Kiemelendő, hogy a gyermek szülei elváltak, édesanyjával, anyai nagyszüleivel, illetve testvérével él egy háztartásban, édesapjával a kapcsolattartás rendszeres.

Szülei visszaemlékezése szerint a gyermek 3 éves kora körül már szembetűnő volt, hogy bár felnőttes szófordulatokkal, választékosan fejezi ki magát, nehézségei vannak az önkifejezés terén (például nem kér segítséget, nem jelzi a fájdalmat, stb.). Szúk körü érdeklődés és repetitív játéktevékenység jellemezte, emellett szenzoros érzékenység is megjelent auditív modalitásban. Kortársaihoz nem kapcsolódott, közösségben hamar elfáradt, frusztrálódott. Iskolai tanulmányait 6 évesen kezdte meg, iskolai teljesítménye azonban elmaradt a kortársaiéhoz képest, elsősorban figyelemkoncentrációs nehézségei miatt. Kudarcélményei mentén másodlagos hangulati tünetek jelentek meg. Iskolai problémái miatt a területi Pedagógiai Szakszolgálat vizsgálta; intelligenciavizsgálata alapján átlag-magas övezeti intellektus került megállapításra.

Gyermekpszichiátriai diagnosztikája során hetero- és autoanamnézis-felvétele, kétszemélyes helyzetben történő exploráció, kortárs közösségben való viselkedésmegfigyelés történt, emellett az alábbi, diagnosztikus munkát, differenciáldiagnózist segítő eszközöket használtuk: Gyermek Mini Nemzetközi Neuropszichiátriai Interjú (Mini International Neuropsychiatric Interview for Children: MINI-KID) [18, 19], Figyelemhiányos Hiperaktivitási Zavar Pontozóskála IV. (Attention Deficit/ Hyperactivity Disorder Rating Scale IV - ADHD-RS) [20], valamint Képességek és Nehézségek Kérdőív (Strengths and Difficulties Questionnaire - SDQ) szülői változat $[21,22]$.

A diagnosztikus folyamat végén ASD és ADHD komorbid fennállása volt megerősíthető.

\section{Terápia}

A diagnosztikus folyamat eredményei alapján a következő komplex terápiás javaslatot tettük, melyet a gyermek és édesanyja egyaránt elfogadtak: autizmusspecifikus szociális-kommunikációs készségfejlesztés és vizuális eszköztár bevezetése, kognitív viselkedésterápia hangulatzavar-fókusszal, illetve metilfenidát-monoterápia megkezdése naponta $20 \mathrm{mg}$, hosszú hatású készítmény formájában, per os. A komplex terápia mellett a gyermek figyelemkoncentrációs kapacitása és feladathelyzetben történő együttmúködése javult, a tanórákat teljes időtartamukban követni tudta, házi feladatait el tudta készíte- 
ni. A gyermekpszichiátriai gondozás során rendszeresen felvett ADHD-RS alapján tüneteit gyógyszeres terápia mellett kompenzálta. Kiemelendő, hogy a gyermek a gyógyszeres terápia megkezdését követő 2 hétben enyhe étvágycsökkenésről számolt be, súlyvesztés ezt azonban nem kísérte. Egyéb mellékhatásról a család a gyógyszerbeállítást követő 1 hónap elteltével nem számolt be. 6 hónap elteltével az édesanya jelezte, hogy a gyermek kétoldali emlőmegnagyobbodásról, illetve -érzékenységről számol be. A metilfenidát-terápia azonnali leállítása mellett gyermekendokrinológiai vizsgálata történt: a dokumentáció szerint az emlők tapintásos vizsgálata során mindkét emlő almányi, mirigyes tapintatú volt, érintésre a gyermek fájdalmat jelzett. Az endokrinológiai szakvélemény alapján a tünetek „inkább a pubertas kezdeti fázisára jellemző átmeneti, de kezelhető állapot” jeleiként voltak értelmezhetők. Az endokrinológus szakorvos javaslata alapján a gyermek 10 napon át naponta $2 \times 1$ tabletta (100 mg/nap) dózisú klomifénterápiában részesült, mellyel - a metilfenidát-terápia leállítását követően 14 nappal - a gynaecomastia a jobb oldalon visszahúzódott; a bal oldali emlőben még észlelhető volt mirigyes tapintat, ezért a gyermekendokrinológus a klomifénkúra ismétlése mellett döntött, változatlan dózisban. 1 hónap elteltével endokrinológiai kontrollja során a gyermek panasz- és tünetmentes volt, vizsgálata további endokrinológiai gyógyszeres terápiát nem indikált. Fontosnak tartjuk kiemelni, hogy a klomifénkezelést a gyermeket vizsgáló gyermekendokrinológus indikálta, a dokumentáció alapján 'Tbl. Clostiltbegyt' formájában. Kliensünk gyermekpszichiátriai gondozása folytatódott, 3 hónap gyógyszermentes időszakot követően - tekintettel arra, hogy kezdődött az iskolai tanév, és a gyermek ADHDtünetei számos területen ismét funkciókárosodást okoztak, illetve figyelembe véve az endokrinológiai szakvéleményt - a gyermek metilfenidát-terápiáját szoros gyermekpszichiátriai kontroll mellett visszaállítottuk. A gyermek ADHD-tüneteit illetően ismét azonnali javulás volt tapasztalható, 1 hónappal a metilfenidát-monoterápia visszaállítása után azonban ismét kétoldali gynaecomastia alakult ki; emiatt a metilfenidát-terápia azonnali leálllítása mellett ismételt gyermekendokrinológiai kontrollra került sor, melynek alkalmával a fizikális vizsgálat keretében mindkét emlőben baracknyi mirigyes állomány volt tapintható. Gyermekendokrinológus javaslatára vérből történő hormonszintvizsgálat ( $\mathrm{LH}, \mathrm{FSH}$, tesztoszteron, ösztradiol, DHEA-S, prolaktin) történt; a normáltartománytól való eltérés semelyik vizsgált hormon tekintetében nem mutatkozott. A páciens 10 napon át ismét naponta $2 \times 1$ tabletta $(100 \mathrm{mg} / \mathrm{nap})$ dózisú klomifénterápiát kapott; rendszeres gyermekendokrinológiai kontrollja történt, amely a tünetek ismételt megjelenésétől számítva 4 hónap elteltével volt lezárható. Tekintettel arra, hogy gyermekpszichiátriai indikációjú gyógyszeres terápia nélkül a gyermek ADHD-tünetei markáns - másodlagos hangulati tünetképzéshez vezető - funkciókárosodást okoztak, atomoxetin-monoterápia felépítése történt a gyermek testtömegének megfelelő 80 $\mathrm{mg} /$ nap fenntartó dózisig. Atomoxetinmedikáció mellett a gyermek az ADHD tekintetében kompenzálttá vált, 18 hónapon át tartó nyomon követése során sem gynaecomastia, sem egyéb mellékhatás nem jelentkezett.

\section{Megbeszélés}

A gynaecomastia az Európai Gyógyszerügynökség (European Medicines Agency, EMA) által jóváhagyott, metilfenidát hatóanyag-tartalmú készítmények alkalmazási előiratában megtalálható a „ritka mellékhatások” kategórián belül, vagyis - a hatósági meghatározás alapján 10 000-ből legalább 1 esetben, de 1000-ből kevesebb mint 1 esetben fordul elö; ennek a besorolásnak a bizonyítékalapja azonban nem nyilvánvaló. Ugyanakkor annak ellenére, hogy az FDA „Nemkívánatos események jelentési rendszere" elnevezésű adatbázisában 2016-ig 35, metilfenidát-alkalmazással összefüggő gynaecomastiaesetet regisztráltak [12], a metilfenidát hatóanyag-tartalmú készítményeknek az FDA által jóváhagyott jelenlegi és nemrég felülvizsgált alkalmazási előirataiban a gynaecomastia nem szerepel a lehetséges mellékhatások között [23] (1. táblázat).

A fentiek alapján úgy tünik, hogy a különféle nemzeti gyógyszerügyi hivatalok mint hatóságok által jóváhagyott dokumentumok is ellentmondanak egymásnak a metilfenidát-kezelés és a gynaecomastia közötti esetleges összefüggés témakörében. További bizonytalanságot jelenthet, hogy a gynaecomastia mint tüneti jelenség szakirodalma is csak korlátozott információt nyújt ebben a vonatkozásban, illetve hogy kevés számú esettanulmány érhető el, melyek viszont gyakran releváns részleteket mellöznek. Mindezek miatt fontosnak tartottuk, hogy beszámoljunk a témában észlelt klinikai esetünkről.

Kiemelendő, hogy a gyermeknél mind az ASD, mind az ADHD diagnózisa fennállt, illetve hogy kezelése során két külön alkalommal is történt metilfenidát-terápia indítása, mely mindkét esetben gynaecomastia kialakulásához vezetett, míg a gynaecomastia a metilfenidát-terápia leállítását követően mindkét alkalommal regrediált.

Felmerül a kérdés, hogy a komorbid állapotnak (ASD, ADHD) lehet-e esetleg szerepe a metilfenidát-kezelés során jelentkező gynaecomastia kialakulásában. A mentális betegségek diagnosztikai és statisztikai kézikönyvének 5. kiadása (Diagnostic and statistical manual of mental disorders, 5th edition, DSM-5) a korábbi kiadású klasszifikációs rendszerrel ellentétben lehetővé teszi az ASD és az ADHD együttes diagnosztizálását [24]. Ezen változtatást követóen módosították az American Academy of Child and Adolescent Psychiatry által kiadott gyakorlati útmutatót is, így abban először szerepelt, hogy ASD fennállása esetén is alkalmazható metilfenidát hatóanyag-tartalmú gyógyszeres terápia. Posey és mtsai [25] publikációjukban megemlítik, hogy vizsgálatuk alapján az ASD és az ADHD együttes előfordulása során magasabb volt a mellékhatás miatt leépített gyógy- 
1. táblázat |Az elmúlt 10 évben publikált esetek összehasonlító táblázata (Kollárovics, Nagy, Balázs 2021)

\begin{tabular}{|c|c|c|c|c|c|c|c|c|}
\hline & Nem & Életkor & Diagnózis & $\begin{array}{l}\text { Fam. end. } \\
\text { anamn. }\end{array}$ & $\begin{array}{l}\text { Gyógyszeres } \\
\text { terápia } \\
\text { (fenntartó dózis) }\end{array}$ & $\begin{array}{l}\text { Metilfenidát- } \\
\text { alkalmazás } \\
\text { időtartama a } \\
\text { gynaecomastia } \\
\text { megjelenéséig }\end{array}$ & Mellékhatás & Kimenetel \\
\hline $\begin{array}{l}\text { Hoevenaren } \\
\text { et al. }\end{array}$ & Fiú & 8 év & $\mathrm{ADHD}$ & $\begin{array}{l}\text { Prepub. } \\
\text { Kétoldali } \\
\text { gynaecomastia }\end{array}$ & $\begin{array}{l}\mathrm{mph} 30 \mathrm{mg} / \mathrm{nap} \\
\text { melatonin } 5 \mathrm{mg} / \text { nap }\end{array}$ & Nincs adat & $\begin{array}{l}\text { Egyoldali } \\
\text { gynaecomastia }\end{array}$ & Mütéti kezelés \\
\hline Ensat et al. & Fiú & 12 év & ADHD & Nincs adat & $\mathrm{mph} 10 \mathrm{mg} / \mathrm{nap}$ & 2 év & $\begin{array}{l}\text { Kétoldali } \\
\text { gynaecomastia }\end{array}$ & $\begin{array}{l}\text { Mútéti kezelés } \\
\text { (mastectomia) }\end{array}$ \\
\hline $\begin{array}{l}\text { Coskun } \\
\text { et al. }\end{array}$ & Fiú & 10 év & $\begin{array}{l}\text { ADHD, szociális } \\
\text { szorongásos zavar }\end{array}$ & Negatív & $\begin{array}{l}\mathrm{mph} 54 \mathrm{mg} / \mathrm{nap} \\
\text { paroxetin } 20 \mathrm{mg} / \mathrm{nap}\end{array}$ & 1,5 év & $\begin{array}{l}\text { Kétoldali } \\
\text { gynaecomastia }\end{array}$ & $\begin{array}{l}\text { Gynaecomastia } \\
\text { utánkövetése alatt } \\
\text { (fél éven át) nem } \\
\text { rendeződött }\end{array}$ \\
\hline Almis et al. & Fiú & 9 év & $\mathrm{ADHD}$ & Negatív & $\mathrm{mph} 18 \mathrm{mg} / \mathrm{nap}$ & 23 nap & $\begin{array}{l}\text { Kétoldali } \\
\text { gynaecomastia }\end{array}$ & $\begin{array}{l}\text { Gyógyszerleállítást } \\
\text { követően } \\
\text { rendeződött }\end{array}$ \\
\hline $\begin{array}{l}\text { Karayag- } \\
\text { murlu et al. }\end{array}$ & Fiú & 15 év & ADHD & Nincs adat & $\mathrm{mph} 36 \mathrm{mg} / \mathrm{nap}$ & 2 hónap & $\begin{array}{l}\text { Kétoldali } \\
\text { gynaecomastia }\end{array}$ & $\begin{array}{l}\text { Gyógyszerátállítást } \\
\text { követően rendeződött }\end{array}$ \\
\hline
\end{tabular}

ADHD = figyelemhiányos hiperaktivitási zavar; fam. end. anamn. = familiaris endokrinológiai anamnézis; mph = metilfenidát; prepub = prepubertás

szeres terápiák aránya a kizárólag ADHD-s csoporthoz képest, de mások nem számoltak be hasonló megállapításról. Egy friss, átfogó tanulmány az ADHD-kezelésben használatos összes gyógyszer témájában mindössze 4 randomizált, kontrollált vizsgálat esetében számol be metilfenidát-kezelésről ASD-ben [26]; ezek alapján a mellékhatások tekintetében nem volt eltérés a korábbi tapasztalatokhoz képest. A metilfenidátnak az ASD típusos tüneteire gyakorolt hatásairól is keveset tudunk.

A klinikus számára meglepő lehet, hogy a gynaecomastia kialakulásának hátterében nem volt azonosítható jelentôs hormonális eltérés. A bevezetőben ismertetett, korábbiakban közölt 5 esettanulmányból 4 esetben szintén a normáltartományon belül voltak a hormonális paraméterek [13, 15-17], míg l esetben erről nincs információ. Endokrinológiai szempontból pozitív családi anamnézis is csak 1 esetben fordult elő [13], 2 tanulmány erről nem tesz említést, 2 tanulmányban pedig kifejezetten jelzik, hogy negatív az endokrinológiai családi anamnézis.

A metilfenidát bevitelétől a gynaecomastia kialakulásáig lezajló pontos mechanizmusokat illetően erôs a bizonytalanság. Felmerül a megnövekedett ösztrogénszint vagy az alacsonyabb androgénszint szerepe $[27,28]$ egyaránt. Fontosnak tartjuk megemlíteni, hogy Adriani és mtsai [29] patkányokon végzett állatkísérleteik alapján metilfenidát beadásával összefüggésben alacsonyabb tesztoszteronértékekről számolnak be.

Tudomásunk szerint hivatalos klinikai ajánlás egyik diszciplínában sincs a témára vonatkozóan. A gyermekpszichiátriai gyakorlatot tekintve - mindhárom szerző gyermekpszichiáter - szakirodalmi ismereteink és a bemutatott eset tapasztalatai alapján úgy gondoljuk, hogy mivel a gynaecomastia súlyos, akár mútéti beavatkozást igénylő formája is megjelenhet, a gondozás során fontos monitorozni, nyomon követni a gynaecomastia kialaku- lásának jeleit (sternumtáji fájdalom, emlőmegnagyobbodás, tapintásra fájdalmi reakció, érzékenység) és detektálásuk esetén azonnal, véglegesen leállítani a metilfenidátterápiát. Az ADHD hatékony kezeléséhez alternatívaként rendelkezésünkre áll más hatásmechanizmusú hatóanyag (atomoxetin) is. Eddigi ismereteink alapján úgy véljük, hogy a metilfenidát-terápia beállításának mérlegelése során a pozitív familiáris endokrinológiai anamnézis esetében nehezen jelezhető előre, hogy mekkora a gynaecomastia kialakulásának kockázata. Ugyanakkor a familiáris endokrinológiai anamnézis ismerete elősegítheti a gynaecomastiának mint esetleges mellékhatásnak a fokozott monitorozását, az esetkövetés során a gyakoribb ellenőrzés megtervezését a gondozás során. Megítélésünk szerint a gyermekendokrinológiai gyakorlatban gynaecomastia megjelenése esetén érdemes az anamnézist gyermekpszichiátriai irányban is ellenórizni.

Esettanulmányunk korlátja, hogy sajnos nem áll rendelkezésünkre ultrahangfelvétel az emlókről. A gyermekendokrinológiai vizsgálat és gondozás részletesebb folyamatáról páciensünk dokumentációja, illetve információ korlátozottan volt elérhető számunkra, a gyermekendokrinológus kollégával nem valósult meg a kapcsolatfelvétel. Limitáció továbbá, hogy a gyermek hormonális laboratóriumi lelete nem áll rendelkezésünkre, illetve hogy a hormonszintek vonatkozásában prospektív követés a rendelkezésünkre álló információk alapján nem történt, ezért a hormonszintek esetleges változásának dinamikáját sem tudjuk bemutatni.

Esettanulmányunk felhívja a gyakorló orvoskollégák figyelmét a metilfenidát-terápia alkalmazása mellett potenciálisan kialakuló gynaecomastia monitorozásának jelentőségére, különösen az ASD és ADHD komorbiditások esetében, hiszen az ASD-ban érintett gyermekeknél - a társas kommunikáció nehézségei, valamint az ön- 
monitorozás, a testi változások megfigyelésének esetleges sajátosságai miatt - fokozott annak kockázata, hogy a metilfenidát-terápiában részesülő, autista gyermek kevésbé monitorozza önmagát, nehezebben számol be testi változásairól, esetleg számára kellemetlen vagy fájdalommal járó testérzeteiről.

Anyagi támogatás: A közlemény elkészítésével kapcsolatban a szerzők anyagi támogatásban nem részesültek.

Szerzôi munkamegosztás: K. N.: A szakirodalmi adatok áttekintése és a klinikai tapasztalatok lejegyzése a kézirat elkészítéséhez. N. P.: A szakirodalmi adatok áttekintése és annak lejegyzése. B. J.: A szakirodalmi adatok áttekintése és szakmai szupervízió biztosítása. A disszkusszió szempontjainak kialakítása révén mindhárom szerző hozzájárult a kézirat elkészítéséhez. A cikk végleges változatát valamennyi szerző elolvasta és jóváhagyta.

Érdekeltségek: A szerzóknek pénzügyi és egyéb érdekeltségeik nincsenek.

\section{Köszönetnyilvánítás}

Köszönet a Vadaskert Kórháznak, amely közös munkánk szellemi múhelye volt. Köszönjük az érintett fiatalnak és családjának, hogy hozzájárultak az eset megjelentetéséhez.

\section{Irodalom}

[1] Barkley RA. The North American Perspective on attention defi cit hyperactivity disorder. J Aust Educ Develop Psychol. 1996; 13: 2-23.

[2] Barkley RA, Cook EH, Diamond A, et al. International consensus statement on ADHD. January 2002. Clin Child Fam Psychol Rev. 2002; 5: 89-111.

[3] Brown RT, Freeman WS, Perrin JM, et al. Prevalence and assessment of attention-deficit/hyperactivity disorder in primary care settings. Pediatrics 2001; 107: E43.

[4] Kutcher S, Aman M, Brooks SJ, et al. International consensus statement on attention-deficit/hyperactivity disorder (ADHD) and disruptive behaviour disorders (DBDs): Clinical implications and treatment practice suggestions. Eur Neuropsychopharmacol. $2004 ; 14: 11-28$

[5] Santosh PJ, Taylor E. Stimulant drugs. Eur Child Adolesc Psychiatry 2000; 9: S27.

[6] Howes OD, Rogdaki M, Findon JL, et al. Autism spectrum disorder: consensus guidelines on assessment, treatment and research from the British Association for Psychopharmacology. J Psychopharmacol. 2018; 32: 3-29.

[7] Groenman AP, Schweren LJ, Dietrich A, et al. An update on the safety of psychostimulants for the treatment of attention-deficit/ hyperactivity disorder. Expert Opin Drug Saf. 2017; 16: 455464.

[8] Nordt CA, DiVasta AD. Gynecomastia in adolescents. Curr Opin Pediatr. 2008; 20: 375-382.

[9] Johnson RE, Murad MH. Gynecomastia: pathophysiology, evaluation, and management. Mayo Clin Proc. 2009; 84: 10101015.

[10] Goldman RD. Drug-induced gynecomastia in children and adolescents. Can Fam Physician 2010; 56: 344-345.
[11] Bowman JD, Kim H, Bustamante JJ. Drug-induced gynecomastia. Pharmacotherapy 2012; 32: 1123-1140.

[12] Maciejewski M, Lounkine E, Whitebread S, et al. The powers and perils of post-marketing data analysis: quantification and mitigation of biases in the FDA Adverse Event Reporting System. bioRxiv 2016; 068692 .

[13] Hoevenaren IA, Schott DA, Otten BJ, et al. Prepubertal unilateral gynecomastia: a report of two cases. Eur J Plast Surg. 2011; 34: 395-398.

[14] Ensat F, Edelbauer M, Wechselberger G. Unilateral gynecomas tia in a prepubertal boy. Eur J Pediatr. 2012; 171: 197.

[15] Coskun M, Adak I, Akaltun I. Bilateral gynecomastia in a preadolescent boy while under treatment with methylphenidate and paroxetine. J Clin Psychopharmacol. 2014; 34: 537-538.

[16] Almis BH, Almis H, Celik M, et al. Methylphenidate induced gynecomastia in a prepubertal boy: a case report. Anatolian $\mathrm{J}$ Psychiatry 2016; 17(Suppl 3): 74-76.

[17] Karayagmurlu A, Varli AT, Coskun M. Gynecomastia: a rare adverse effect of methylphenidate in an adolescent boy. Clin Psychopharmacol Neurosci. 2020; 18: 337-339.

[18] Sheehan DV, Sheehan KH, Shytle RD, et al. Reliability and validity of the Mini International Neuropsychiatric Interview for Children and Adolescents (MINI-KID). J Clin Psychiatry 2010; 71: 313-326.

[19] Balázs J, Bitter I, Hideg K, et al. The Hungarian version of the MINI and MINI Plus. [A MINI és a MINI Plusz kérdő́iv magyar nyelvú változatának kidolgozása.] Psychiatr Hung. 1998; 13: 160-168. [Hungarian]

[20] DuPaul GJ, Power TJ, Anastopoulos AD, et al. ADHD Rating Scale-IV: checklists, norms, and clinical interpretation. Guilford Press, New York, NY, 1998.

[21] Goodman R. The Strengths and Difficulties Questionnaire: a research note. J Child Psychol Psychiatry 1997; 38: 581-586.

[22] Túri E, Gervai J, Áspán N, et al. Validation of the Hungarian version of the Strengths and Difficulties Questionnaire in an adolescent clinical population. [A Képességek és Nehézségek Kérdőív (SDQ-Magy) validálása serdülőkorú klinikai populációban.] Psychiatr Hung. 2013; 28: 165-179. [Hungarian]

[23] Food and Drug Administration. Label of methylphenidate. FDA, Silver Spring, MD, 2017. Available from: https://www.accessdata.fda.gov/drugsatfda_docs/label/2013/010187s077lbl.pdf [accessed: March 15, 2021].

[24] American Psychiatric Association. Diagnostic and statistical manual of mental disorders. Fifth edition. American Psychiatric Association, Washington, DC, 2013.

[25] Posey DJ, Aman MG, McCracken JT, et al. Positive effects of methylphenidate on inattention and hyperactivity in pervasive developmental disorders: an analysis of secondary measures. Biol Psychiatry 2007; 61: 538-544

[26] Reichow B, Servili C, Yasamy MT, et al. Non-specialist psychosocial interventions for children and adolescents with intellectual disability or lower-functioning autism spectrum disorders: a systematic review. PLoS Med. 2013; 10: 1001572.

[27] Ismail AA, Barth JH. Endocrinology of gynaecomastia. Ann Clin Biochem. 2001; 38: 596-607.

[28] Braunstein GD, Glassman HA. Gynecomastia. Curr Ther Endocrinol Metab. 1997; 6: 401-404.

[29] Adriani W, Leo D, Guarino M, et al. Short-term effects of adolescent methylphenidate exposure on brain striatal gene expression and sexual/endocrine parameters in male rats. Ann $\mathrm{N} \mathrm{Y}$ Acad Sci. 2006; 1074: 52-73.

Kollárovics Nóra dr., Budapest, Raoul Wallenberg u. 2., 1. em. 2., 1136, e-mail: norakollarovics@gmail.com)

A cikk a Creative Commons Attribution 4.0 International License (https://creativecommons.org/licenses/by/4.0/) feltételei szerint publikált Open Access közlemény. (SID_1) 